\title{
Rapanui Placenames: Keys to the Mysteries
}

\author{
Sergei V. Rjabchikov \\ Krasnodar, Russia
}

\begin{abstract}
A number of placenames are investigated which shed light upon the culture of Easter Island.
\end{abstract}

Easter Island (Rapa Nui), "the center of the world" according to the local views, keeps many secrets. Placenames are important sources that can help to decode the mysterious culture of this island (Rjabchikov 1993a; 1996a; 1996b; 1996c; 1997a; 1997b). This report deals with several placenames which are key ones for understanding Rapanui ethnology. It is necessary to keep in mind the rules of the gradual phonetic evolution of the Polynesian languages in order to read some of the names successfully.

The Rapanui Creation Chant contains the name Tiki-te-Hatu 'Tiki-the lord', associated with Tiki, the first man or the god creator in central and marginal Polynesia (Métraux 1940, 321, 323). This god in the ancient New Zealand religion is regarded as the deity Tane's creative power, and Tane is a personified form of the sun (Buck 1938, 265; Best $1955,16)$. So one can suppose that the Rapanui placename Hatu o puna (Barthel 1962, 105) is connected with this religious idea. Indeed, the ghost Puna is mentioned in a myth (Métraux 1940, 312-313). Puna was always looking at the priestess and she was watching over the skull, an incarnation of the god creator Makemake (Tiki, Tane, Tangaroa.) The name Puna is also included in the four placenames Ahu puna hoa, Ahu puna kape, Ahu puna poho, and Ahu puna rere takatea (Barthel 1962, 104). Rapanui ahu signifies 'ceremonial platform', hoa is 'friend', kope is 'son', 'young person'; Maori poha is 'youngest child of a family' or 


\section{Names 46.4 (December 1998)}

'full', rere is 'to rise or to set, as heavenly bodies'; Rapanui rere is 'to fly', taka is 'round', 'bright red', takataka is 'sphere', 'round', tea is 'white', and takatea is 'semen'. Obviously these terms describe the solar cult.

The ceremonial platform, Ahu puna hoa, is described by Thomson: "although in ruins, this has evidently been a structure of some importance; 175 feet long..." (1891, 505). Near this platform American investigators found a peculiar stone buried in the earth. The natives called this nearly spherical stone Petakula. I believe that it was a symbol of the sun. The name Petakula consists of peta (Rapanui pata 'clot of blood') and kura (Rapanui kurakura 'fair, light'; Tuamotuan kurakura 'red'). The wordplay is quite possible: Rapanui tiko 'menstruation', Tiki 'the sun deity', katiki 'the solar corona', komari 'vulva'; and Maori komaru 'the sun'.

Interestingly, the name of the main statue on Easter Island, Hoahaka-nana-ia, also contains the word hoa 'friend', and the petroglyph of the sun is depicted on its back (Rjabchikov 1993b). Additionally, the name of the god, ${ }^{1}$ Rarai-a-Hoa, is literally 'the sun-friend'. The placename Ara horenga (Barthel 1962, 105) denotes 'The road of the yellow friend (the sun)', i.e., 'the ecliptic'. The placename Toka mitiake (Barthel 1962, 107) signifies 'the sun' (lit. 'the sphere ${ }^{2}$ of the great dryness').

As has been shown (Rjabchikov 1997a), the placename Ahu tahai is a reflex of solar worship as well. The placename $R a$ tahai (Barthel 1962 , 107) includes the term $r a$ ( $\left.r a^{\prime} a\right)$ 'the sun': Moreover, in accordance with Rapanui legends (Barthel 1978, 2-4), Ratavake was an initial settler of Easter Island; he lived at Mataveri, also connected with the solar cult (Rjabchikov 1996a). Therefore it is natural to divide the hero's name into $r a\left(r a^{\prime} a\right)$ 'the sun' and tavake 'tropic bird'. I think that it is a hint at the birdman Makemake's cult since this god is represented on rock drawings as a person with the head of a frigate bird (Métraux 1940).

The placename Te kana haure correlates with Tuamotuan kana 'bright', 'gleaming' (Barthel 1978, 174). I believe that haure is comparable to Tahitian hau 'king' and Rapanui ree 'victor'. Indeed, Makemake was the deity of warriors (Lee 1992). Glyph 49 of the Easter Island writing system ${ }^{3}$ with the standard reading (ariki) mau 'supreme 
chief, king' has the variant 49b, which consists of glyphs 14 hau and 41 (e)re. Also the term kana is like Rapanui kena 'booby bird', and as indicated above, the bird cult is united with the solar cult.

Both the placenames Uimahara and Te uirenga (Barthel 1962, 107) contain Rapanui $u i$ 'to look'. The term mahara can be compared with Maori mahora 'exposed to view', spread out' and is mentioned in the Maori expression He mata mahora no te ara whanui a Tane, which describes the sun deity Tane (Best 1954, 19). Again, renga 'yellow' has the figurative meaning of 'sun'. On the strength of these examples the name of the sun deity Maui (Best 1954, 33) can be interpreted as Ma-ui where ma corresponds to Maori ma 'white, clean' and whakama 'to make white. ${ }^{4}$

The map of Easter Island by W.J. Thomson (1891) contains two ancient placenames. The first, Ko Tatake M[ountain] has been replaced by the name Tangaroa on modern maps. It should be pointed out that both names have similar meanings: Rapanui take signifies 'initiation', Maori take 'chief', Rapanui taka 'round', 'bright red', takataka 'sphere', 'round', and this complex is due to the sun god Makemake/ Tane/Tiki/Tangaroa (Rjabchikov 1997c). The second, the placename Rana Hana Kana presented on Thomson's map is replaced by the name Tere (a) Vaka on modern maps. My research (Rjabchikov 1996b, 2556), shows that this place (lit. 'The boat goes away') is named for the boat of the sun god and the moon goddess. In addition, Rapanui rano means 'volcano'; Tuamotuan hana means 'the sun'; Rapanui hana means 'heat' and Tuamotuan kana means 'bright' or 'gleaming'.

The ancient Easter Islanders decorated their chicken houses with the signs of rei-miro pendants, and these ornaments are symbols which promote fertility (Barthel 1978). This custom is reflected in the placename Puku ure pu rei (Barthel 1962, 107): the term rei compares with Rapanui rei-miro 'pendant in the form of a canoe', $p u$ means 'to produce', ure means 'penis', and puku means 'hill'. It is well to bear in mind that hieroglyph 8 represents the pendant rei-miro and reads matua 'hull of canoe', 'parent'. Additionally, the corresponding Hawaiian string figure, ${ }^{5}$ also representing a canoe, is called hapua-kane 'male child' or hapua-wahine 'female child'. Furthermore, hapu signifies 'pregnant' in both Maori and Tahitian. 


\section{Names 46.4 (December 1998)}

\section{Notes}

1. Perhaps an image of this god is seen in the statue Hoa-hakanana-ia.

2. Cf. also Rapanui toka 'flat stone'.

3. I use my own classification and translation scheme for reading the rongorongo glyphs (Rjabchikov 1987).

4. In a like manner, I split Maori uira 'gleam', 'flash' into $u i$ and $r a$ (cf. Maori $r a$ 'the sun').

5. See Rjabchikov (1997b, 48 table).

\section{References}

Barthel, T.S. 1962. "Easter Island Place-Names." Journal de la Société des Océanistes 18:100-107.

. 1978. The Eighth Land. The Polynesian Discovery and Settlement of Easter Island. Honolulu: U of Hawaii P.

Best, E. 1954. Some Aspects of Maori Myth and Religion. Dominion Museum Monograph No 1. Wellington: R.E. Owen, Government Printer.

. 1955. The Astronomical Knowledge of the Maori. Dominion Museum Monograph No 3. Wellington: R.E. Owen, Government Printer.

Buck, P.H. (Te Rangi Hiroa) 1938. Vikings of the Sunrise. Philadelphia and New York: Lippincott.

Lee, G. 1992. The Rock Art of Easter Island. Symbols of Power, Prayers to the Gods. Los Angeles: The Institute of Archaeology Publications (UCLA).

Métraux, A. 1940. Ethnology of Easter Island. B.P. Bishop Museum Bulletin 160. Honolulu: Bishop Museum Press.

Rjabchikov, S.V. 1987. "Progress Report on the Decipherment of the Easter Island Writing System." Journal of the Polynesian Society 96: 361-7.

. 1993a. "Rapanuyskie texty (k probleme rasshifrovki)." Etnograficheskoe obozrenie 4: 124-41.

. 1993b. Interpretatsiya nazvaniya moai Hoa-haka-nana-ia. Krasnodar: Kubansky Kur'er. 
- 1996a. "Toponimy ostrova Paskhi, svyazannye s kul'tom ptitsecheloveka." V.I. Tkhorik (ed.) Otnositel'nost' abstraktnykh realiy yazyka. Krasnodar: Kuban State University, pp. 141-4.

. 1996b. "Easter Island Place-Names: Myths and Reality." Beiträge zur Namenforschung. Neue Folge 31: 255-9.

. 1996c. "Rongorongo versus Kai-kai: A Look at Parallel Themes in Easter Island's Mysterious Script and String Figure Repertoire." Bulletin of the International String Figure Association 3: 14-20. . 1997a. "A Key to Mysterious Easter Island Place-Names." Beiträge zur Namenforschung. Neue Folge 32: 207-10.

. 1997b. "Rongorongo versus Kai-kai: A Second Look at Themes Linking Easter Island's Mysterious Script with Its String Figure Repertoire." Bulletin of the International String Figure Association 4: 30-55.

. 1997c. "The Rapanui Chant 'He Timo te Akoako': Origin and Interpretation." Paper presented at the Third International Conference on Oceanic Linguistics and Pacific Area Contact Linguistics Association, January 9-15, 1997, University of Waikato, Hamilton, New Zealand.

Thomson, W.J. 1891. "Te Pito te Henua, or Easter Island." Report of the United States National Museum for the Year Ending June 30, 1889. Annual Reports of the Smithsonian Institution for 1889. Washington: Smithsonian Institution, pp. 447-552. 